\title{
Digitizing Primary Data on Biodiversity to Protect Natural History Collections Against Catastrophic Events: The type material of dragonflies (Insecta: Odonata) from Museu Nacional of Brazil
}

\author{
Marcus Vinícius Oliveira De Almeida $\ddagger$, Ângelo Parise Pinto§, Alcimar do Lago Carvalhoł \\ ‡ Museu Nacional, Universidade Federal do Rio de Janeiro, Rio de Janeiro, Brazil \\ $\S$ Universidade Federal do Paraná, Curitiba, Brazil
}

\begin{abstract}
Corresponding author: Marcus Vinícius Oliveira De Almeida (mvoalmeida@gmail.com), Ângelo Parise Pinto (ap pinto@ufpr.br)
\end{abstract}

Received: 15 Sep 2021 | Published: 16 Sep 2021

Citation: De Almeida MVO, Pinto ÂP, Carvalho AL (2021) Digitizing Primary Data on Biodiversity to Protect Natural History Collections Against Catastrophic Events: The type material of dragonflies (Insecta: Odonata) from Museu Nacional of Brazil. Biodiversity Information Science and Standards 5: e75284.

https://doi.org/10.3897/biss.5.75284

\begin{abstract}
Natural history collections (NHC) are guardians of biodiversity (Lane 1996) and essential to understand the natural world and its evolutionary processes. They hold samples of morphological and genetic heritages of living and extinct biotas, helping to reconstruct the timeline of life over the centuries (Gardner 2014). Primary data from specimens in NHC are crucial elements for research in many areas of biological sciences, considered the "bricks" of systematics and therefore one of the pillars for evolutionary studies (Troudet 2018). For this reason, studies carried out in NHC are essential for the development of the scientific knowledge and are pivotal for the scientific-technological progress of a nation (Camargo 2015).

The digitization and availability of primary data on biodiversity from NHC represents a inexpensive, practical and secure means of exchanging information, allowing collaboration between institutions and researchers. In this sense, initiatives such as the Sistema de Informação sobre a Biodiversidade Brasileira (SiBBr), a country-level branch of the Global
\end{abstract}


Biodiversity Information Facility (GBIF) platform, aim to encourage and establish ways for the informatization of biological collections and their type specimens.

Known for housing one of the largest and oldest collections of insects in the world focused on Neotropical fauna, the Entomological Collection of the Museu Nacional of Federal University of Rio de Janeiro (MNRJ) had more than 3,000 primary types and approximately $12,005,000$ specimens, of which about $96 \%$ were lost in the tragic fire occurred at the institution on September 2, 2018. The $\underline{\mathrm{SiBBr}}$ project was active in that collection from 2016 to 2019 and enabled the digitization and preservation of data from the type material of many insect orders, including the charismatic dragonflies (order Odonata). Due to the end of the agreement between $\mathrm{SiBBr}$ and the Museu Nacional, most of the obtained primary data are pending full curation and, therefore, are not yet available to the public and researchers.

The MNRJ housed the biggest and most important collection of dragonflies among all Central and South American institutions. It assembled most of the physical records of neotropical dragonfly fauna gathered over the last 80 years, many of which are of undescribed taxa. Unfortunately, almost all material was permanently lost. This study aims to gather, analyze and publicize primary data of the type material of dragonflies housed in the MNRJ, ensuring the preservation of its history, as well as providing data on the taxonomy and diversity of this marvelous group of insects.

A total of 11 families, 50 genera and 131 species were recorded, belonging to the suborders Anisoptera and Zygoptera with distributional records widespread in South America.

The MNRJ housed 105 holotypes of dragonflies' nomina representing $11.7 \%$ of the richness of the Brazilian Odonata fauna (901 spp.), a country with the highest number of species of the biosphere. The impact of the loss of this collection to studies of these insects is unprecedented, since some enigmatic and monotypic genera such as Brasiliogomphus, Fluminagrion and Roppaneura lost $100 \%$ of their type series, while others most diverse such as Lauromacromia, Oxyagrion and Neocordulia lost $50 \%, 35 \%$ and $31 \%$ of their holotypes. Therefore, due to the registration and preservation of primary biodiversity data, this work reiterates the importance of curating and digitizing biological scientific collections. Furthermore, it shows extreme relevance for preserving information on existing biodiversity permanently and providing support for future research. Digitization and interconnecting digital extended specimen data proves to be one of the main and most effective ways to protect $\mathrm{NHC}$ heritage and their primary data against catastrophic events.

\section{Keywords}

odonates, damselfly, biological data, zoological collections, Latin America, taxonomy, Arthropoda, invertebrates 


\section{Presenting author}

Marcus Vinícius Oliveira De Almeida

\section{Presented at}

TDWG 2021

\section{Funding program}

Coordination for the Improvement of Higher Education Personnel (CAPES PROEX, process \#88887.335792/2019-00)

\section{References}

- Camargo AJA, et al. (2015) Coleções entomológicas: legislação brasileira, coleta, curadoria e taxonomia para as principais ordens. EMBRAPA, Brasília, 1-118 pp. URL: https://ainfo.cnptia.embrapa.br/digital/bitstream/item/122542/1/amabilio-01.pdf

- $\quad$ Gardner JL, et al. (2014) Are natural history collections coming to an end as timeseries? Frontiers in Ecology and the Environment 12 (8): 436-438. https://doi.org/ 10.1890/14.WB. 012

- Lane MA (1996) Roles of Natural History Collections. Annals of the Missouri Botanical Garden 83 (4): 536-545. https://doi.org/10.2307/2399994

- Troudet J, et al. (2018) The Increasing Disconnection of Primary Biodiversity Data from Specimens: How Does It Happen and How to Handle It? Systematic Biology 67 (6): 1110-1119. https://doi.org/10.1093/sysbio/syy044 